The writer wishes to express his hearty thanks to Prof. Dr. A. Yuasa, University of Tokyo and Prof. Dr. H. Ito, Tokyo University of Education, for their influential instructions and also to Prof. Dr. T. Miwa, Tokyo University of Educa-

\title{
References
}

1) Hartman, M. E. Bot. Gaz. 91: 252 (1931). 2) Igura, I. Bot. Mag. (Tokyo) 68: 119 (1955 a). 3) McClung, J. R. McClung's Handbook of Microscopical Technique. 3 rd ed., New York (1950). 4) Ohara, K. The Journal of Biology (published by "The Congress of the Scientific Research of the Ministry of Education ") 1: 1 (Japanese) (1947). 5) Pfeifer, H. H. Planta 37: 96 (1949) (Biol. Abst. A. 24: 1352, 1950). 6) Cytologia 16: 194 (1951). 7) Verdoorn, F. et al. Manual of Pteridology. Hague. (1938).

\section{Studies on the Development of the Peristome in Musci II.}

\section{On the Peristome in Dicranum japonicum Mitt}

\author{
by Shintaro SAITo*
}

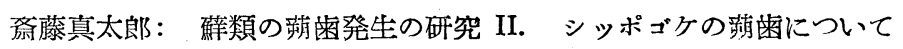

\section{Received November 8, 1955}

From the standpoint of the development of peristomes, Cavers ${ }^{3}$ ) divides the Bryales into the following four groups, namely, Tetraphidales, Polytrichales, Buxbaumiales and Eubryales. In the former two groups, the teeth of the peristome are composed of entire cells, while in the latters they are composed of thick-walled cells. And the Eubryales is further devided into the Diplolepideae and Haplolepideae by Philibert4). The former with few exceptions has double peristomes, while the latter has single peristome.

In the Diplolepideae the two peristomes are derived from the two concentric layers of cells in the opercular portion of the capsule. The development of the peristome has been described in Funaria hygrometrica ${ }^{5}$, Mnium hornum ${ }^{6}$, Mnium microphyllum ${ }^{9}$ and Bartramia crispata ${ }^{10}$ among several species of this group. In

\footnotetext{
* Biological Institute, Faculty of Literature and Science, Shimane University. (島根大学交理学部生物学教室)
} 
these species the outer peristomial layer is composed of thirty-two longitudinal rows of cells and the inner one of sixteen rows, thus, these rows consist of groups, each of which consists of two cells of the outer layer lying opposite one cell of the inner layer in the cross section.

In the Haplolepideae the single peristome is likewise derived from two concentric layers of cells in the opercular portion of the capsule. And as for this group Evans \& Hooker1) published a work on the same subject in Ceratodon purpureus, but no further special study on this subject has been followed. In this species the outer peristomial layer is composed of sixteen longitudinal rows of cells and the inner one of twenty-four longitudinal rows of cells, and the cells of the peristomial layers form eight groups, each composed of two rows of cells of the outer layer and three rows of the inner layer. And each of those groups gives rise to two teeth. Consequently, the total number of the teete amounts to sixteen. And in this case each tooth of this group is homologous with the inner peristome of the Diplolepideae.

In the present article, the author deals with the development of the peristome in Dicranum japonicum, a member of the Haplolepideae.

\section{Materials and Methods}

The materials for the present study were collected by the auther from Sept. 1953 to Oct. 1954, at Matsue, Shimane Prefecture. Bouin's solution was used as the fixing agent. The paraffin sections were cut at $10 \mu$ thick and stained with Delafield's haematoxylin.

\section{Development of the peristomial layers}

In the present species the opercular segments are divided into quadrants by anticlinal walls. Cross sections through the opercular region of young capsules just below the apical cell show the feature clearly (Fig. 1). This quadrant is the fundamental square and each cell of which is further divided into the outer cells (amphithecium) and the inner cells (endothecium) by the first periclinal walls (Fig. 2). The four cells of ths amphithecium develop into the eight-celled stage by the following anticlinal walls (Fig. 3). And a similar arrangement of the cells can be demonstrated in the early stage of the development of the amphithecial cells divided by periclinal walls, thus giving rise to two amphithecial layers of eight cells each (Fig. 4). In the region of the operculum, successively the stage shown in Fig. 4, the cells of the outer layer are divided by anticlinal walls, thus increase the number of cells to sixteen (Fig. 5). And then the amphithecial layer forms two layers which are made of sixteen cells respectively by the formation of periclinal walls in each cell (Fig. 6) of which the inner layer develops into the outer peristomial layer. The cells of the inner amphithecial layer undergo no further divisions and develop into the peristomial layer. The cells of the outer layer are 
further divided by anticlinal walls into thirty-two-celled layer and the endothecium begins to divide (Fig. 7). The cells of the outer amphithecial layer are divided by more anticlinal and periclinal walls. During the increasing of cells in the amphithecial layer, the eight cells of the inner amphithecial layer (Figs. 6, 7), correspon-

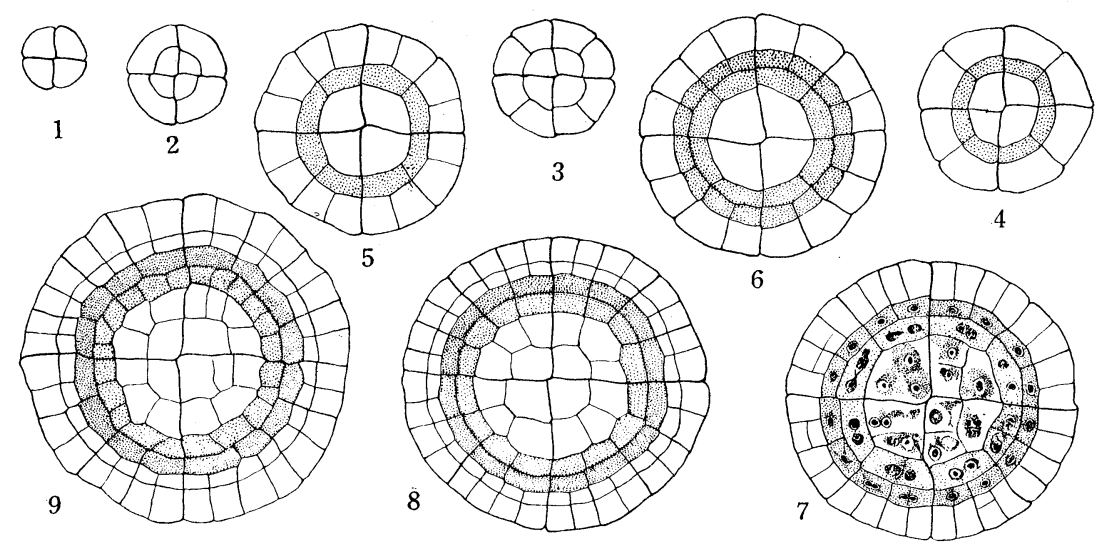

Figs. 1-9. Cross sections through the opercular region of young capsules, showing successive stages of development of peristomial layers stippled $\times 300: 1$. Division of segments to the quadrant or "fundamental square"; 2. Establishment of amphithecium and endothecium; 3. eight-celled stage of an amphithecial layer divided by anticlinal walls; 4. Showing an inner peristomial layer divided by periclinal walls; 5. Division of cells in outer amphithecial layer by anticlinal walls; 6. Showing an outer peristomial layer divided by periclinal walls; 7 . Division of cells in an inner peristomial layer by anticlinal walls; 8, 9. Continuation of divisions in outer amphithecial layer and endothecium.

ding to the inner peristomial layer, increase to about 24 in number by the formation of anticlinal walls and undergo no further divisions (Figs. 8,9). Thus, in cross section each of the eight groups comprises three cells of the inner peristomial layer lying opposite two cells of the outer one and develops into two peristome teeth (Figs. 9-12). In longitudinal section the rows of cells of both outer and inner peristomial layers taking part in the formation of the peristomes number from thirty-seven to forty rows. In the view of the longitudinal sections of the upper regions of young capsule, showing the successive stage of development of the teeth, the number of cells in the full length of peristome amounts from twenty to twentyfive (Fig. 14).

\section{Deposition of the peristomial thickenings}

As above described, the peristomial layer is divided into eight groups, in which the three rows of the inner peristomial layer correspond with the two rows of the outer layer. And a group gives rise to two teeth of the peristome and the same process is produced in each group. The deposition of the peristomial thickenings takes part on the outer periclinal walls of the cells circumscribed to the endothecium 

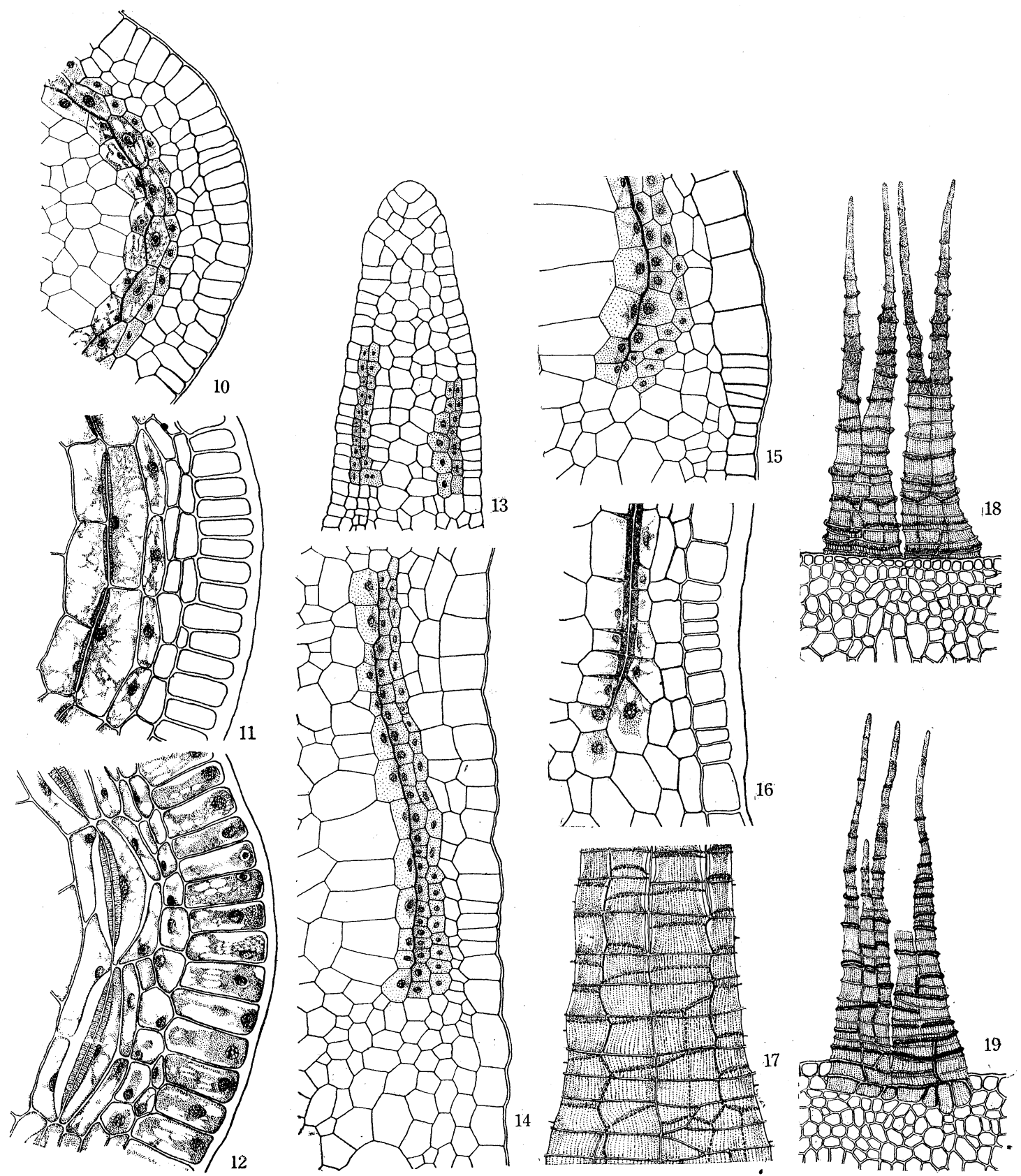

Figs. 10-12. Cross sections through the amphithecial tissues of older capsules stippled $\times 300$ : 10. Showing the peristomial layers in the region of the teeth, just before the deposition of the thickenings; 11, 12. Early stage in the development of the thickening with the adhesion and disappearance of cytoplasm and nuclei.

Figs. 13-19. Radial sections in the region of the teeth, showing the peristomial thickenings in their successive stage of development stippled, $\times 300$, and teeth of young and old capsules: 13, 14. Showing total length of peristomial layer in an early stage; 15 , 16. Showing their thickening in the regions of the basal portion of peristomes; 17. Tangential section of basal portion of the young peristome, $\times 200$; 18,19 . Fully developed teeth, $\times 110$ (18, seen from outside; 19 , inside). 
(Figs. 10-12). As the capsules swell, the regions of their opercula become distinguished from the capsules. Just before the thickenings are deposited, the peristomial cells taking part in thickening lead to the swelling of their nuclei and usually provide with vacuoles (Figs. 10, 11). And then the cytoplasm and nuclei in the peristomial cells are adhered to the part of the thickenings (Figs. 10, 11, 12, 14, $15,16)$.

In succession with the deposition of the peristomial thickenings, the cytoplasm coheres to the part of the thickenings and the vacuoles expand, but the disappearance of the both cytoplasm and nucleus is followed (Fig. 16). After the adhesion and the disappearance of the cytoplasm and nuclei throughout the peristomial thickenings, the initial thickening begins in the basal portion of the peristome and thickening essentially undergoes in the same process throughout the branches of the peristomes (Figs. 15, 16). The lamellae of the inner side of peristome teeth are well developed, especially they are more pronounced in the basal part of the same. There are also seen a few longitudinal ridges between each lamella. In other words the peristomial thickenings continue with the thickenings on the inner wall and give rise to the transverse ridges of the mature peristomes. In the young stage the transverse and longitudinal thickenings are seen in tangential section, and the same appearance is more striking in an older tooth (Figs. 17-19).

In a word the thickenings extend almost over the inner periclinal walls and on the radial and transverse walls extend as ridge. Soon after the thickenings have been deposited uopn the teeth, the peristomial cells dry up, the thin parts of the walls shrivel away and disappear, and the teeth become free.

\section{Considerations}

In the Haplolepideae the cell divisions of the young sporophyte proceed regularly, and the pattern of the cell divisions is the same with that of Mnium, Funaria and Bartramia, each of which is member of Diplolepideae.

In the amphithecial tissue of the young capsule, the two concentric layers of cells are produced from sixteen cells of the outer peristomial layer and thirty-two cells of the inner layer are seen in each species above said. In Ceratodon purpureus the inner peristomial layer is composed of twenty-four rows of cells, while in Dicranum japonicum it is composed from twenty to twenty-four rows of cells, yet the inner peristomial layer is formed by the unequal cells in both shape and size as seen in Ceratodon purpureus. Such a feature was not seen in Mnium microphyllum $^{9)}$ and Bartramia crispata. ${ }^{10}$ ) Toward the base of the branches of teeth the transverse ridges grow wider and wider until finally some of them coalesce:with each other in Ceratodon purpureus, while in Dicrauum japonicum the transverse ridges get nearer each other and increase their stripes in number. The deposition of the thickenings in the peristomial layer is equivalent on the outer and inner 
sides of the middle lamellae. In the Diplolepideae the transverse ridges adhere to the inner wall of the peristomial layer, but not to the outer wall as is the case of the Diplolepideae. In Dicranum japonicum the vestiges of the radial walls form a zigzag longitudinal line on the inner surface of the tooth, but not on the outside as in Diplolepideae. Of course this line is much shorter than that in Mnium microphyllum and Bartramia crispata, in which the teeth are not divided into branches. The single peristome of Dicranum japonicum is homologous with the inner peristome of the Diplolepideae.

\section{Summary}

1. The amphithecium and the endothecium are derived from the cell of quadrant, and the amphithecium is divided further into the inner and outer peristomial layers by periclinal walls.

2. The inner peristomial layer arises from the inner amphithecial layer, undergoing cell division until it is composed of $20-24$ cells in cross section by the formation of anticlinal walls.

3. The outer peristomial layer comes to have sixteen cells in cross section by the formation of anticlinal walls. These sixteen cells of the layer undergo no further division.

4. Both peristomial layers form eight groups, each of which is composed of 2 rows of the outer layer and 2 or 3 (mostly 3 ) rows of the inner layer, and gives rise to two teeth.

5. The ridges of thickening, corresponding to the peristome are laid upon the periclinal walls between the two (inner and outer) peristomial layers.

6. Before the thickenings are deposited, the nuclei in the cells of two layers taking part in the formation of the teeth, are enlarged. And then the protoplasm of both inner and outer peristomial cells moves towards the outer walls of the inner peristomial cells. Following the thickenings the vacuoles appear in cell cavity and both the cytoplasm and the nuclei gradually shrivel away and disappear.

Finally the writer expresses many thanks to Dr. Akira Noguchi, Prof. of the Kumamoto University for his kind abvices.

\section{Literature cited}

1) Evans, W. \& Hooker, D. Bull. Torry Bot. Clab. $40: 97$ (1913). 2) R. von der Wijk Morphologie und Anatomie der Musci, in Verdoon's Man. Bryol. 31-38 (1932). 3) Cavers, F. The inter-relationships of the Bryophyta. New Phytologist Reprint, 4:182 (1911j. 4) Philibert, H. De 1' importance du péristome pour les affinités naturelles des mousses. 2e article. Rev. Bryol. 11: 65-72 (1884). 5) Campbell, D. H. The structure and development of mosses and ferns. Second edition. New York. p. 211 (1905). 6) Strasburger, E. Das botanische Practicum. 4te Auflage. Jena. p. 491 (1902). 7) Noguchi, A. Jour. Hattori Bot. 6:24 (1951), 8:5 (1952). 8) Gilbert M. Smith. Cryptogamic Botany 2: 96 (1955). 9) Saito, S. \& Nishita, Y. Bull. Shimane Univ. $4: 84$ (1954). 10) Saito, S. \& Shimoze, S. Bot, Mag. Tokyo 68: 55 (1955). 